\title{
Foresight as Social Hygiene: Interview with Alioune Sall and Geci Keruri-Sebina
}

In this interview by Aidan Eyakuze and Arthur Muliro, Professor Alioune Sall and Dr Geci Keruri-Sebina reflect on their experience in using foresight to influence policy at the national and city level. Differences in expectations, language and perceptions of time between foresight practitioners and their policy-making interlocutors are identified as obstacles to its deeper effectiveness in shaping policy in Africa. Unsurprisingly, the seriousness of individual policymakers in engaging with foresight and acting on its insights matters a great deal, as demonstrated by Mauritius and Johannesburg. They argue that ultimately, regardless of whether every individual initiative is effective, doing foresight is a socially hygienic activity.

AM: Alioune, you have three decades or more of having worked on the African continent with foresight starting with the African Futures Initiative, what has been significant about the practice and how has it contributed to helping governments and institutions arrive at better decisions.

AS: What is striking is the fact that there was a lot of naivety. Forty years ago there was a sense that we could plan in an environment of certainty and that if African countries were able to attract financial resources, we could be able to pick up very quickly and move. The idea that something might go wrong at that time or that new developments could take place that could force us to revise our hypotheses was not there. A simple idea of constructing a scenario was seen as an unnecessary luxury. I remember at the time taking great pain to explain why it was necessary to try and consider different possible trajectories.

Today it is not very difficult to explain or convince decision-makers and policymakers that the future is an area of uncertainty. This is a big step forward. Now, how this knowledge has been incorporated in the policy formulation process has not been easy. From my experiences in working with different countries, I have seen that trying to operationalize vision that has come from foresight exercise has been quite a difficult process for at least three reasons.

One is that the foresight community is quite different from the community of decisionmakers and there are a very limited number of platforms where they have been able to interact. The community of foresight practitioners mainly comprises people from academia and research institutes. Those who are involved in policy formulation usually come from line ministries, presidents' offices and planning commissions. They don't necessarily speak the same language and some difficulty of communication explains to a certain extent why the operationalization through policy and reform is also difficult. 
Secondly, those involved in policy want a certain degree of certainty and are not ready to take risks. The tools that they use are mainly based on extrapolation and they find it difficult to incorporate discontinuity in their thinking. I do not know of a planning model that incorporates discontinuity.

Another reality is the fact that foresight practitioners and policymakers do not have the same notion of time. Government people have a notion of long term that does not go beyond the next election cycle because their legitimacy does not go beyond that period. The community of foresight practitioners have a different understanding of what long term means. The fact that they have two different temporalities becomes a problem because the sense of urgency is not the same.

AE: Are they irreconcilable?

AS: No, but it has been a challenge in a number of countries I have been working with. Unfortunately in our (African) countries the higher echelons of public service are politicized and therefore with any cabinet change you will always have changes in the public service, which is not the case in countries like France. But the fact that you that the civil service is to a large extent insulated from political change is needed. This enables the civil servants to think through what happens and who will be able to push it through. Many countries, in fact, do not have that kind of continuity and I think that has made the whole issue very difficult. The only country that has been an exception in my view has been Mauritius. After the National Long Term Perspective Study was conducted, the Director of Planning became Governor of the Reserve Bank, Minister of Planning and ultimately Minister of Finance. Wherever he went he carried prospective studies and ensured they were not lost in translation. That played a significant role in seeing Mauritius carrying forward exercises and translate the scenarios and the vision into programme frameworks.

AE: Geci, in a previous conversation you said that the attempt to embed foresight into South Africa's national planning system sort of failed. One of the reasons mentioned by Alioune was different notions of time or temporalities. Is that correct and what do you think could have been done?

GKS: Saying it didn't work is my own perspective. If you ask the government they would say they made good use of the skills and that's how South Africa got a national development plan. The conversation we tried to have with them was if you're going to embark on a process of national planning let's talk about the tools that we are going to use to get there'. Their feeling at that stage was that South Africa had already done several rounds of long-range studies, stories and cartoons and therefore they didn't need to do foresight. Interestingly, we found out they later went to do a week of foresight at Oxford focused on key driving forces that they were going to use for an analytical process. But they felt that the idea of systematic use of foresight methods meant 'scenarios' and if foresight was just going to contribute some more stories, it has already been done.

AS: I think there are some attempts to institutionalize foresight in Mali and now there's a new Ministry of Planning and Prospective in Benin. But what is happening is that in those countries is that prospective is seen simply as a way to elaborate or formulate some kind of vision, it's not really all foresight. They still find it difficult to see how foresight activities can be related to planning.

AM: Alioune, you said earlier that we live in the period of uncertainty, when you speak to policymakers. Do you find that when you discuss the various options, they feel empowered by understanding that this is what might be coming and therefore they embrace it? Or do they continue to see it as an esoteric mental exercise?

AS: They understand what is changing, but they understand it in a very narrow sense. What they want to do is show that something is happening.

AM: In practical terms, on the issue of temporality and the imperative of the election cycle, how can we turn foresight into something that engages into those spaces rather than expect those spaces to engage in the logic of foresight?

GKS: I think at the urban level, the bigger cities do some long-range planning. Right now there is Johannesburg 2040, Pretoria/Tshwane 2055, Ekhurhuleni 2055. Cape Town and Durban have 
several. However, they were also done in these very discrete points in time. It is somewhat amusing because what would happen is that you would have Johannesburg 2030, next thing you're talking about Johannesburg 2040 which begs the question 'What happened to Johannesburg 2030? Has it been resolved in any way?' So it's sort of just the creating of plans and the dismissing of plans. You attempted to address the long term but from a series of very short-term perspectives.

We actually commented on this, and what we have shown is that, unfortunately, these long-range plans often or vertically have no connection. You will find that it is a national plan that has nothing to do with the long-range plan of a particular space or set of spaces that might be 60 percent of your economy. You can't say that it does not matter that the plans do not align. It does matter because there is nothing you're talking about nationally without 60 percent of your economy.

What I see as positive movement there, is that in terms of institutionalization the one thing that has happened is that it is still personally driven. It's the mayor and therefore it's his vision and his plan. However, in Johannesburg, for example, what we have seen as really interesting is their complete realignment of the whole institution to the plan. We have also seen a lot of institutional realignment to saying that, 'Ok if that is the long range perspective that we have got as a city, then in a sense all of our five-year or ten-year strategies should all also begin to speak to that'. We have local government elections in 2016 so we will see whether the plan survives a new administration, if there is one. I think we actually have seen very concrete and extensive consultation around the 2040 process which did not happen with the 2030 process.

AM: Are you pessimistic or optimistic about the effectiveness, the ability of foresight to influence policy in Africa?

GKS: I don't know for sure whether brushing my teeth will prevent tooth decay but it is worth doing. So I see it as a bit of a hygienic factor to do foresight. I really think it's something one cannot dispense with. You have got to act with foresight and, as you said, no one serious about the endeavour they are in, doesn't in some way conduct foresight. For me it's a question, especially the governance space, of how systematically and with what degree of deliberateness one does foresight. I think that's what a number of us foresight champions argue for is that there is some value in thinking through things, understanding the tools you can use, seeing when and where you can use them and whether they will be adequate in terms of ensuring you have made the best decisions. So for me it's not about being optimistic or pessimistic, I think you should just do it. And then you must make sure in general that you're doing things and finding yourselves in conditions where you can succeed.

AS: I concur with Geci. We just have to make it clear that we should not fool ourselves by thinking that we can change things overnight. But we should also not be so pessimistic or so defeatist that we accept the idea that there is nothing we can change or there are very few things that we can change. We owe it to ourselves and to our community, to show that there are alternative futures and to shed some light on what we see in them. For me this is just simply a matter of ethics, a matter of responsibility to say and to share views about what is possible in expanding the horizon, that's the price you have to pay if you want to be a good citizen. To a large extent foresight is also about positioning oneself in life and having to appreciate life. So it's not simply a theoretical issue, it's about what is it that makes you tick and where can you find people you can live with, you can talk with or who you want to see in the future. I think my final take away is that it's hygienic. I think it's a great metaphor to say that just as you would brush your teeth in the morning, you better do foresight. It is hygienic, it is good manners. 